\title{
Change management at clusters: first results of a change management survey among clusters at European level
}

\author{
Völgyiné Nadabán Márta \\ INNOVA Észak-alföld Regionális Fejlesztési és Innovációs Ügynökség Nonprofit Kft., Debrecen \\ marta.nadaban@eszak-alfold.hu
}

SUMMARY

\begin{abstract}
Change is a natural characteristic of organisations at the end of the twentieth century and in the upcoming ages. The dynamism of the environmental effects and the heterogeneity of the environment urge organisations to continuously adapt to these changes. It means that organisations and clusters which are more or less agglomeration of organizations should be open to external influences and those organisations responding faster are more viable. From the professional literature several change management methods and tools are known. However, few sources deal with clusters. A cluster is also a unique organizational structure: its specialty lies in the fact that even large clusters are built up from smaller organisations in an environment where flexibility, rapid economic decisions and high level buoyancy is needed. The question is whether the general change management methods and approaches can be interpreted regarding clusters.
\end{abstract}

Keywords: change management, cluster

\section{INTRODUCTION}

In today's unstable environment, when managers and professionals are looking for something constant and stable to grip, the most stable and most consistent stability they can find is the change itself. We all must recognize the message of 'Nothing is more permanent than change' and in today's world only those who can accept and adapt to the accelerated and constantly changing environment will be successful.

In my representation the changing is a continuous pliancy to the assumption of the environment. The environment hands over the effects and forces that also force the organizations for pliancy that means different behavior and different work.

The clusters as agglomeration of companies and other actors of a specific sector are working in this changing environment also. The change is not only around a cluster it is also within a cluster. Changing and also the need for changing are always presented in the life of clusters. Since the innovative and competitive atmosphere is the base of the flexible environment, these factors can also be the barriers of the development (Sölvell et al., 2009). If the flexibility expected from the cluster disappears and the cluster cannot react fast and effectively for the changing environment, the decline procedure may start at the cluster. So it is very important for the cluster management to know the toolkits of the change management and to apply them in the everyday work.

The purpose of apply for this conscious change management is:

- development of the adaptation ability of the cluster,

- prepare the cluster and its members for "collapse" with the eternal changing and challenging environment and

- for the unexpected effects.

\section{MAIN FEATURES OF CLUSTERS AND CHANGE MANAGEMENT}

Grasselli and Völgyiné (2011) dealt with the characteristics of clusters in detail. Our study is based on work and now I present the most important results.
The meaning of 'cluster' is group, a set, figuratively it can also mean: a partnership, uniting, collaboration or coalition. Clusters, particularly the business clusters play an important role in explaining the geographic concentration of the economic and innovation processes. In this study the term 'cluster' refers to a business / economic / research cluster.

The definition of cluster gives a modern explanation to a long term observed phenomenon of geographical concentration of economic activities, which is a widely expected factor of economic development. Marshall (1890) already noticed the beneficial effects of the concentration of economic activities, which was primarily manifested in the availability of skilled labor and its specialization. Schumpeter (1939) also made reference to the concentration of operating companies in the industrial sector. The definition of the cluster is very broad and contains a large number of conceptual elements which look back to the distant past.

The definition is built on the location site and agglomeration theories. It also includes other theories, such as industrial districts, growth poles, new industrial spaces, production systems, innovation environment, national or regional innovation systems, learning and creative region, etc.

Michael Porter (1990) considered the concentration of the economic activity observed in the clusters as the results of the competitive advantages of the companies through which new and better methods are identified in the given intra-industral competition and the companies appear faster on the market with their innovative products. According to Porter, a business cluster is the "geographical concentration based on competition of cooperative and competitive companies, related and supporting industries and financial institutions."

Another widely used definition which comes from UNIDO (UNIDO) says ,a cluster is the sectoral and geographical concentration of companies, which produce and sell wide ranges of related or complementary products. Therefore, they face common challenges and opportunities. This kind of concentration can contribute to rise of the external economic units such as specialized suppliers or raw material and competent suppliers, it promotes 
the growth of the sector's professional knowledge base and contributes the development of specific technical, managerial and financial services.

While the different schools and those not introduced here highlight different elements which are essential in the growth and operation of a cluster, several common factors can be observed in each cluster definition:

- A cluster is a group of specialized firms, skilled labor and supporting institutions in a geographic concentration.

- Clusters also serve the objective to provide a wide range of specialized and customized services to specific businesses.

- In this sense, clusters are self-developing organisations to create competitive advantages for enterprises.

- The geographical proximity of enterprises promotes the flow of hidden knowledge and the so-called unintended interactions, which are essential elements of the innovation process.

- A cluster can integrate the different innovation actors into one organisation. It can also strengthen the interactions and relationships between them.

- The intensive - often spontaneous - formal and informal relationships and business information, know-how and technical expertise within the cluster can often lead to new and unexpected ideas, products and services, which can significantly increase the innovation performance.

As a result of the previous characteristics clusters can be best defined rather by their relationships than their memberships. Their territorial boundaries are variable and these boundaries are not necessarily the same as the political borders. An organisation can react to the changes in environmental conditions in many different ways. According to management and organisation professional literatures, experts and employees primarily focus on the question of structural changes. The question of changing organizational structure is really a key issue because these changes fundamentally affect the operation of companies (clusters and cluster members).

We also have to accept that at the work and behavior caused by changes at the organization (cluster) there are organizational effects for the cluster and the members of the cluster. From this aspect we can really realize that those structural changes are the most important that are focusing on the change of the organizations so these are the structural changes.

We can consider as structural or organization change any changes which happens in the substantial characteristics of the single organization (Dobák, 1999). These are the followings:

- operational processes,

- technologies,

- organizational outputs,

- organizational structure,

- organizational culture and behavior,

- organizational power structure.

As organizations are complex systems, these aspects influence or determine each other. We can see that the organizational change appears in several different levels (see above) at the same time.

Today the adaptation to a rapidly and continuously changing environment requires many changes from organisations which do not require structural change but they can significantly affect the operation of organisations. In many cases, only attitude, and thus behavioural changes are sufficient for the adaptation. Operation and structure are closely related organizational characteristics which often move together or at least their interaction is unquestionable. Therefore it is not appropriate to distinguish between the changes affecting the function and structure because the process of change and its nature are the same.

According to the traditional management approach, organizational change can be regarded as 'directed change', so managerial involvement is assumed. The process of change can be planned, controlled, namely it is controllable (Bakacsi, 2001). The recognition of the guided nature of organizational changes is difficult if the change is not initiated by the management. 'Of course, that does not mean that the leadership could not use the changes already in progress for its own purposes.' Successful leaders often claim the processes originally started independently with their own initiatives; thus, the processes become managed ones. According to this approach the organizational changes in each case must be understood as controlled changes because the term 'organizational change' itself refers to the active participation of leadership (Kiss, 1991).

According to Pataki's (2004) work (which is based on Watzlawick et al., 1974, 1990; Smith, 1982; Levy, 1986), two basic types of changes can be distinguished:

(1) The morphostatic (first degree) change takes place within the frame of the given system while the system itself remains unchanged.

(2) The morphogenetic (second degree) change is the change of the system itself.

Change management is a professional field dealing with the management of the second degree (morphogenetic) changes (Mink et al., 1993).

According to Conner (1993) three types of changes can be possible:

- Micro-changes which affect me, my partner, the family and close friends;

- Organizational changes which occur at workplaces or at any other institutions involved in my life (eg. religious communities or clusters);

- Macro changes, for example in regions.

Many things can change in the life of organisations and clusters, such as the organizational form, strategy, hierarchy, operational profile, human resources, etc. Thus it is difficult to exhaust the previous dimensions of change.

Based on my own experience and the approach in the literature I consider change to be a dynamic process in which the organisations adapt to environmental conditions. Therefore they consciously transform the processes of the organisation.

\section{FOCUS AND METHOD OF THE RESEARCH}

The clusters and cluster member organizations that were implicated in the test and the questionnaires and also in the case study procedure were chosen different way respecting the geographic, sector and organizational aspects. The surveying is focusing not only on Hungarian clusters; it is focusing on clusters in international dimension. 
The aims of the research described in this study are the followings:

- to collect information whether the clusters know and use the cluster management tools and

- get to know which of the tools are used in the different types of problems.

The research tries to find the answer for the possible differences between the different approaches if there are any sectoral, geographical or other explanations. Steps of the planned research:

I. Surveying among clusters.

a1) Small surveying with several clusters,

a2) extended surveying with large number of clusters.

The questionnaire was prepared using both open and closed questions. At most of the questions the respondents have to mark their answer from 0 to 5 making a quality ranking (where 0 is for not applicable; 1 for insignificant and 5 for significant).

The main chapters of the questionnaires are:

a) General data.

b) Survey on cooperation among clusters members. This questionnaire concerns with the cooperation of cluster member organisations. The questionnaire examines the intensity and the activities of the cooperation by clusters. The first part of the questionnaire concerns the cooperation between the organisation and the cluster managing organisation and the second part is focusing on the cooperation between the organisation and other members of the cluster.

c) Survey on applied change management of members of clusters. The aim of the survey is to assess the changes of an organisation belonging to a certain cluster, the changes that have affected the organisations and to find out how conscious management methods were applied in the change management.

This study is presenting the first results of the surveying among some clusters (see a1) as the data collection is still in progress. To prepare this study I elaborated 36 answers, which means that the results of the survey are not representing clusters from sectoral or geographical point of view.

\section{RESULT OF THE RESEARCH}

Regarding the sectoral classification I wanted to find out which are the sectors, where cluster members came from in the highest number in order to be able for identifying this as one possible factor of using different change management techniques by clusters. The first results are shown in the Figure 1. Based on the low number of analyzed questionnaires I cannot make any preliminary conclusion on that factor yet.

As described above the cooperation between the cluster member organizations is crucial for the success of the cluster, which is the reason why several questions are focusing on this factor. The questions were taken about the past three year's relationship between the cluster member organizations and the other types of cluster members. I wanted to know what are the most typical relationships and the level of cooperation between the organizations.

Figure 1: Sectoral classifications of the clusters involved in the research

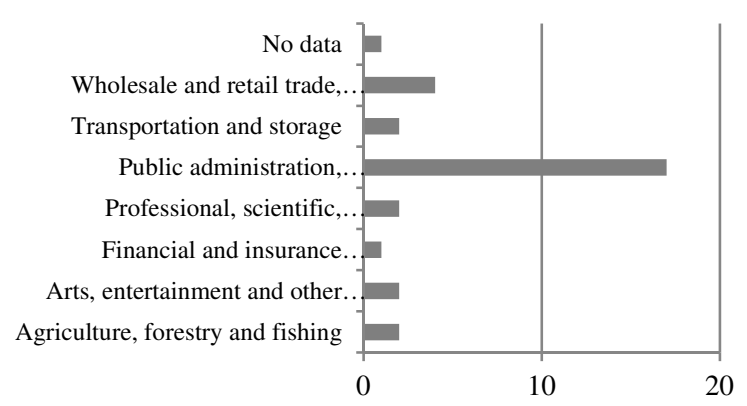

Source: own research

The first results are indicated in the Table 1 as an agglomerated result of the different types of collaboration such as cooperation, coordination, coalition and collaboration in terms of transfer of information to each other; communication and decision-making.

The results of these analysis of the Table 1 show that the level of cooperation of cluster members is on highest level with private organizations, universities and research institutes and it is the lowest with financial organizations (financial institutions, investment funds). Based on the previously analyzed surveys I can assume that the general level of cooperation seems to be low for different kinds of organizations and it seems that the extent of the cooperation differ widely per country and per sector.

\begin{tabular}{|c|c|}
\hline Type of organization & Number of cases \\
\hline Enterprises & 17 \\
\hline Universities, research institutes & 23 \\
\hline Financial institutions & 2 \\
\hline Incubators & 4 \\
\hline NGOs & 7 \\
\hline Investment fund & 1 \\
\hline Local government, development agency, governmental organization & 21 \\
\hline Innovation agency & 6 \\
\hline
\end{tabular}

Source: own research 
I have also tried to measure the effect of different changes of the last 5 years at the organizations which are belonging to a cluster. Results are indicated on the Figure 2.

The results of the analyzed questionnaires (see Figure 2) show significant values in some factors: most respondents considered changes neutrally or more favorably process for the organization. It is very interesting to recognize that most of the organizations have a basically optimistic view of past changes considering the recent economic crisis. These optimistic opinions are more interesting by taking into account the fact that $60 \%$ of respondents answered that they have no knowledge about change management methods.

Regarding to the change management methods, I have tried to determine how the different change management strategies are applied at the organizations (marking the results from 0 to 5 as indicated above). Results are indicated in Table 2.

Figure 2: Effect of changes at the organizations in the last 5 years

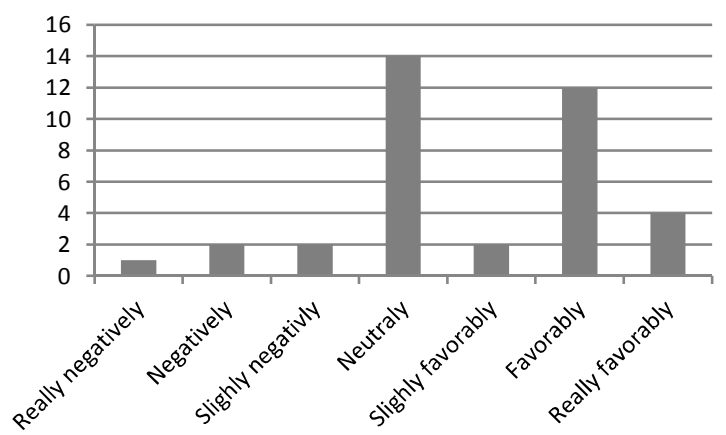

Source: own research

Table 2 .

Application of the different change management tools at the organizations

\begin{tabular}{ccccc}
\hline & $\begin{array}{c}\text { Facilitative } \\
\text { (discounts, reward } \\
\text { opportunities) }\end{array}$ & $\begin{array}{c}\text { Re-educative } \\
\text { (changing of values and } \\
\text { behavior) }\end{array}$ & $\begin{array}{c}\text { Persuasive } \\
\text { (change with arguments } \\
\text { and justification) }\end{array}$ & $\begin{array}{c}\text { Power } \\
\text { (higher position, use } \\
\text { dependence) }\end{array}$ \\
\hline 0 & 16 & 11 & 13 & 15 \\
1 & 7 & 6 & 5 & 8 \\
2 & 5 & 5 & 6 & 5 \\
3 & 3 & 5 & 7 & 2 \\
5 & 4 & 2 & 7 & 1 \\
\hline
\end{tabular}

Source: own research

Results in the Table 2 show that persuasive strategy (change with arguments and justification) and re-education (changing of values and behavior) were evaluated as most used strategies, considering that their value were only on medium level. The significance of facilitation (discounts, reward opportunities) is almost the same as power strategy (higher position, use dependence). Generally, it is obvious that positive nature change management strategies are dominant; however they are on medium level meaning they do not playing an important tool at all. The Figure 3 on frequency of applications of change management methods during change management also underlines this statement.

Figure 3: Effect of changes in the organizations in the last 5 years

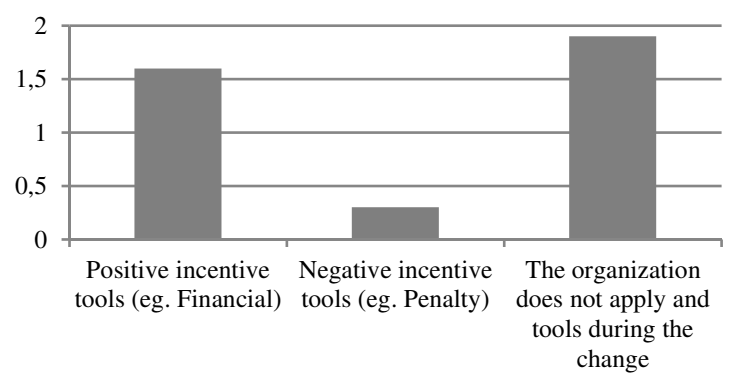

Source: own research
The professional literatures usually say that considering theoretical judgments, positive incentives are usually overemphasized, still in practice negative incentives are dominant. Based on my research (as it is indicated in Figure 3) the negative incentives are underemphasized, the companies are preferring the positive incentives. This result is not in line with the theories. It is still an open question whether there is any correspondence between that judgment and the fact that the survey is focusing on clusters where the collaboration willingness is on high level.

This surveying will be extended on further clusters across Europe. The higher amount of the questionnaires will contribute to statements and consequences what are the differences between the clusters coming from different regions and sectors in order to provide for example recommendations for tools and incentives for the public sector to support their development.

\section{ACKNOWLEDGEMENTS}

The publication is supported by the TÁMOP4.2.2/B-10/1-2010-0024 project. The project is cofinanced by the European Union and the European Social Fund. 


\section{IRODALOM}

Bakacsi Gy. (2001): Szervezeti magatartás és vezetés. KJK-Kerszöv Jogi és Üzleti Kiadó. Budapest.

Conner, D. R. (1993): Managing at the Speed of Change. Villard Books. New York.

Dobák M. (1999): Szervezeti formák és vezetés. Közgazdasági és Jogi Könyvkiadó. Budapest.

Grasselli N.-Völgyiné Nabadán M. (2011): Stratégiai klaszterfejlesztés. INNOVA Észak-Alföld Regionális Fejlesztési és Innovációs Ügynökség. Debrecen. 85-100.

Kiss L. (1991): Integrált termelési - készletezési rendszerek. [In: Dobák M. (szerk.) Vezetés-szervezés.] Aula Kiadó. Budapest.

Levy, A. (1986): Second-Order Planned Change: Definition and Conceptualization. Organizational Dynamics. Summer.

Marshall, A. (1890): Principles of Economics. 8th Edition. Macmillan. London.

Mink, O. G.-Esterhuysen, P. W.-Mink, B. P.-Owen, K. Q. (1993): Change at Work. Jossey-Bass. San Francisco. California.
Pataki B. (2004): Változásmenedzsment oktatási segédlet. Budapesti Müszaki és Gazdaságtudományi Egyetem. Budapest. 52.

Schumpeter, J. A. (1939): Business Cycles. A Theoretical, Historical and Statistical Analysis of the Capitalist Process. McGraw-Hill. New York/London.

Smith, K. K. (1982): Philosophical Problems in Thinking about Organizational Change. [In: Goodman et al. Change in Organizations.] Jossey-Bass. San Francisco. California.

Sölvell, Ö.-Ketels, Ch.-Lindqvist, G. (2009): EU Cluster Mapping and Strengthening Clusters in Europe. European Commission. Enterprise and Industry. Luxemburg. 12.

UNIDO (United Nations Industrial Development Organization) more information are at the homepage of the organization. http://www.unido.org/

Watzlawick, P.-Weakland, J. H.-Fisch, R. (1974, 1990): Change Principles of Problem Formation and Problem Resolution. W. W. Norton \& Co. Inc. New York. USA. 192. 
